\title{
The Fight against Trading in Influence
}

\author{
Willeke Slingerland \\ Saxion University of Applied Sciences, School of Governance \& Law \\ M. H. Tromplaan 28, 7513 AB Enschede, the Netherlands
}

\begin{abstract}
This article explains how considering the systemic character of influence market corruption can help the Council of Europe and its Member States in their fight against trading in influence. By applying article 12 of the Council of Europe's Criminal Convention on Corruption on two recent cases in the Netherlands and France, it is being tested whether the provision provides an effective solution for scrutinising the trading in influence phenomenon. Both cases provide an example of the trading in influence phenomenon, which is symptomatic in western influence markets and which has implications far greater than the ones immediately apparent.
\end{abstract}

Keywords: corruption, influence peddling, trading in influence, influence markets

Raktažodžiai: korupcija, prekyba ịtaka mažesniu ir didesniu mastu, įtakos rinkos.

\section{Introduction}

A fundamental paradox in western societies has emerged: cases concerning trading in influence become more and more imminent and with it the necessity to deal effectively with this phenomenon. International conventions call for the criminalization of this form of corruption but many States are hesitant to establish this form of corruption as a criminal offence under their domestic law. Recent scandals such as the Duchess of York, Sarah Ferguson, promising access to her ex-husband Prince Andrew, who serves as a quasi-official trade envoy for Great Britain, to 'rich businessmen' is just one of the more obvious cases in which a person promises to exert an improper influence over the decision-making process of a public official in return for an undue advantage [8]. Current allegations of the illegal financing of Sarkozy's 2007 election campaign by L'Oreal's heiress Bettencourt and the influencing by the others involved in this case, are exemplary of the value of 'having access to the decision maker'. Trading in influence, or influence peddling, is not something new in the debate on corruption. It found its way in the Council of Europe's Criminal Convention on Corruption (hereinafter 'COE Convention') as early as 1999 [7]. The principal aim of the Convention is to develop common standards concerning certain corrupt offences, although it does not prescribe a uniform definition of corruption. By harmonising the definitions for specific corrupt offences, it aims at meeting the requirement of dual criminality [15, paragraph 6]. The COE Convention has been ratified by 43 States, over one fourth of these States have made a reservation against the undertaking to introduce criminal provisions for 
trading in influence. Among these are the United Kingdom, Denmark and the Netherlands [21]. Nevertheless, allegations of trading in influence and unjustified influencing are omnipresent in media coverage. From the latest COE Convention evaluation and compliance reports, it becomes clear that many of the ratifying States face difficulties in providing adequate legal instruments in their anti-corruption policies to deal with trading in influence. The more surprising it is that the Council of Europe and its Member States were not actively discussing this topic in order to reach a common ground for a provision on trading in influence. Why does the Council of Europe persistently continue to stress the importance of criminalizing trading in influence while some of its Member States are determined in their refusal to criminalize trading in influence without seeking for further dialogue? Few analyses were to be found on this paradox although the topicality of this pressing matter is evident [22]. M. Johnston and M. van Hulten [17;30] are two of the few theorists who have emphasized the importance of increased attention to this form of corruption. In this paper I will explain how, considering the systemic character of trading in influence can help the Council of Europe and its Member States choosing the right instruments to tackle this form of corruption.

\section{Trading in influence in a network society}

Many European societies with developed democracies and market economies have become network societies in which social and other networks shape the organization of society and its structures [6, p.199; 4, p.25-30)]. Different actors (public, semi-public and private) all play a role in and influence the decision-making processes while depending on each others' input to create results. The European integration process, and to a different extent the corresponding processes of liberalization, privatization, harmonization and deregulation, have changed the rules of the political and economic 'decision-making game' within Europe and its States and brought changes to the roles and responsibilities of actors involved and their corresponding ways to strive for their interests [16, p. 288-301; 2, p. 167; 31, p.40-50]. Nevertheless, these developments have become more scrutinized because of the renewed worries about corruption $[17, \mathrm{p} .1]$. The phenomenon to consider is the so-called 'trading in influence' which is considered to be symptomatic for the western societies and the way their decision-making processes take place [17, p. 60 and beyond]. By trading in influence, or influence peddling referral is being made to: the situation where a person misuses his influence over the decision-making process for a third party (person, institution or government) in return for his loyalty, money or any other material or immaterial undue advantage [26, p. 18]. Johnston hereby also distinguishes power-oriented corruption, which will focus on winning offices and influencing those who hold them; corruption in pursuit of wealth will target government contracts, the implementation of policies, or specific aspects of legislation [17, p. 43].

This form of corruption has found its way into the main international conventions on corruption [29, art.18; 7, art. 12]. The COE Convention describes trading in influence in article 12 as: the intentionally, promising giving or offering, directly or indirectly, of any undue advantage to anyone who asserts or confirms that he or she is able to exert an improper influence over the decision making of any person, whether the undue 
advantage is for himself or herself or for anyone else, as well as the request, receipt or acceptance of the offer or the promise of such an advantage, in consideration of that influence, whether or not the influence is exerted or whether or not the supposed influence leads to the intended result. One fourth of the European States have reserved the right not to establish as a criminal offence the conduct referred to in this article. Those States which have made these reservations are criticised by the Group of States against Corruption (hereinafter 'GRECO'), which monitors States' compliance with the Council's anti-corruption standards, for not implementing the provision in a satisfactory manner. What's causing this wide-spread resistance to, and difficulties in criminalizing trading in influence? In order to be able to answer this, first a few remarks will be made on the positions of States which have made a reservation to this provision. Secondly, the provision's efficiency will be tested by applying it to two interesting cases: one case, which has recently taken place in the Netherlands and one which is ongoing in France. Would using the definition of article 12 of the COE Convention, help us to investigate and criminalize trading in influence behaviour?

\section{States' reasons for making a reservation on article 12 COE Convention}

Some of the ratifying States which have made a reservation, have been evaluated by GRECO Evaluation Team (hereinafter GET) in its Third Evaluation Round which started in 2007 and which is still ongoing. States' arguments for their reservations are fourfold.

The first argument is that some States have similar provisions in place which they regard as sufficient in dealing with trading in influence. Germany has not made an official reservation to article 12 of COE Convention but does not incriminate trading in influence. German authorities suggested that some offences like "breach of trust towards the enterprise" may, to some extent, allow addressing this kind of criminal behaviour [11, paragraph 114]. The United Kingdom's 1906 Prevention of Corruption $A c t$, describes as an offence "an agency relationship between a person who trades his influence and the person whom he influences" [28, section 1].The Dutch authorities are of the opinion that at that moment the regular bribery provisions - whether or not in the form of an attempt or in combination with the forms of participation - already sufficiently provide for adequate protection against unauthorised and actual exertion of influence on the administrative system and no separate offence needs to be established in order for this to be a criminal offence [13, paragraph 60 and $61 ; 3$ art.47 and 48; 30 paragraph 171-176]. The Danish' view is that trading in influence is considered to be partly covered by the general rules on complicity in conjunction with private sector bribery [9, paragraph 70]. Swedish authorities declare that most cases of undue influence of persons covered by article 12 of the COE Convention are already criminalized under the provisions of active and passive bribery [12].

The second argument given is that the provision could affect acknowledged lobbying activities. Trading in influence is not explicitly covered by the law in the United Kingdom as it is believed that such a criminalization could affect acknowledged lobbying activities [14, paragraph 91 and 131]. The Dutch authorities maintain that certain forms of influence (whether financial or not) over decisions of public officials or politicians may be lawful, 
for instance where representatives of interest groups perform lobbying activities. The bounds of propriety are only overstepped, when the lobbying or the attempt to exert influence results in holding out the prospect of specific advantages to public officials who are involved in the decision-making process [13, paragraph 60-61]. To regulate this matter would encroach upon legitimate lobbying and free speech. Swedish authorities regard the situations that might not be covered in current legislation to border on lobbying. Lobbying is not considered illegal, but provides an opportunity for NGO's and interest groups to exercise political influence. A criminalization of trading in influence might thus come into conflict with the fundamental right in a democracy to influence people in power or others through exercising the right to freedom of expression [12, paragraph 54].

The third argument relates to the complicated structure and lack of clarity of the provision. The Danish authorities' main reason for not criminalising trading in influence as a separate offence is the complicated structure of this offence [9, paragraph 70]. In its evaluation, authorities do not explain what they mean by this. In the view of the Swedish authorities, neither the Convention, nor the Explanatory Report clearly define "undue influence", against which background the authorities find it difficult to provide a precise definition in criminal law of the acts described in article 12 of the COE Convention [12, paragraph 54].

A fourth argument for making a reservation to article 12 COE Convention is specifically given by French authorities and concerns the reciprocal aspect. Businesses and nationals of Member States which have made a reservation, have an advantage in competition now that this form of influencing decision making is not a criminal offence. In order to minimise this 'unfair advantage', France wants to keep this reservation to allow the influence by a French party on the decision making of a foreign public official or an official or a member of a foreign public assembly. France has criminalized active and passive trading in influence on national decision making [10, paragraph 89].

\section{GET's response}

In response to these objections, GET recommends these States to criminalize trading in influence in accordance with article 12 [11, paragraph 114]. GET has stressed in the Explanatory report to the COE Convention that "the acknowledged forms of lobbying do not fall under the notion of "improper" influence which must contain a corrupt intent by the "influence peddler" [15, paragraph 65]. The provision aims at covering a large variety of situations. GET noted that States could think about certain phenomena which may qualify as trading in influence (for instance with the involvement of elected officials); the introduction of criminal provisions in this area would thus fill a gap. GET also recalls that the establishment of trading in influence as a criminal offence permits the authorities to reach the close circle of officials, or the political party to which they belong, and to tackle so-called "background corruption", which undermines the trust of citizens in the fairness of public administration [9, paragraph 70; 15 paragraph 64]. In its latest Evaluation Reports GET continues to advise States withdrawing or not renewing their reservation relating to this article of the Convention [13, paragraph 91]. 


\section{Applying article 12 COE Convention on two cases}

First the two cases will be shortly introduced and secondly, the provision of article 12 of COE Convention will be applied to the cases.

Case 1: the Dutch DSB case. One of the cases which can illustrate the complexity of trading in influence is the DSB (Dirk Scheringa Bank) case. The Dutch central bank (DNB) granted DSB a banking licence in 2005. DSB was able to grow rapidly because it was active in the market segment, which was regarded as being unattractive by other banks. The bank used aggressive marketing methods to attract clients. Customers, who were not accepted by other banks, were able to get loans from DSB. Mortgages were granted, which they were unable to afford. DSB imposed huge interest rates and used very intimidating tactics to collect payments that were overdue. The financial complexities of DSB's financial products were often discussed as being an example for its overall malpractices. Despite the questionable practices, DSB was successful and financially supported successful football club AZ which plays European football, had its own speed skating team and a DSB-museum with a collection of modern realism paintings. Dirk Scheringa who was the sole shareholder and also CEO, drew in the involvement of several former politicians. Among which, was former Finance Minister Gerrit Zalm, who was appointed as a chief economist and later as the financial director of DSB. The supervisor DNB, perceived the exorbitant interest payments that several financial institutions were now charging as a risk for the entire sector, and urged all banks to make their service charges transparent. According to the central bank, this transparency requirement created large risks, especially for DSB. This supervisor gave several warnings, but did not intervene [33 and 32]. The supervisor of the financial sector the AFM, imposed two penalties on DSB for violating the rules on mortgage interest. DSB received bad press and Sobi, a Dutch foundation dedicated to transparency in financial reporting, called upon customers to withdraw their money, hoping this would lead to bankruptcy which it regarded as the best way to minimise damage. The central bank placed DSB under court receivership and the trustees appointed by the central bank asked the court to declare DSB bankrupt. The damage this brought to DSB's employees, customers, subsidiaries and contractors was staggering. Shortly before the debacle at DSB, Zalm resigned as its $\mathrm{CFO}$ and became $\mathrm{CEO}$ at $\mathrm{ABN}$ Amro, which now was a state-owned bank. The two supervisors, DNB and AFM were asked by the Minister of Finance to investigate the role of Gerrit Zalm in the DSB-collapse. According to the DNB, Zalm acted conscientiously throughout and the DSB-failure had no implications for his new position as CEO for ABN Amro. Te AFM on the contrary, was of the opinion that Zalm had failed to end the criticised practices, during his time at DSB and therefore could not credibly remain in position as CEO for ABN Amro. Formally, having two opposing conclusions is not problematic. The investigation is formally conducted by $\mathrm{DNB}$, and the views of the AFM are only part of the evidence it considers. However, to the outside world, there are two different conclusions. One wonders though what happened after Zalm was appointed as CFO? Did this have an influence on DNB's monitoring task? Did Dirk Scheringa try to escape DNB's scrutiny by attracting Zalm? 
Case 2: the allegations of illegal financing of Sarkozy's election campaign. The previous bookkeeper of France's richest woman Mrs. Bettencourt, has accused her previous employer of secretly financing the election campaign of French President Sarkozy's centre-right UMP party. According to her, Bettencourt's financial advisor has given 150.000 Euros in cash to Mr. Woerth, who at the time was the treasurer of the UMP. Two months after the alleged event took place, Sarkozy was elected as the President of France and Mr. Woerth became the Minister of Labour. His wife became appointed as an investment advisor for Mrs. Bettencourt. From May 2007 until March 2010, Mr. Woerth was also the Minister of Finance, responsible for collecting taxes from the same wealthy persons and companies he is believed to have received donations from. In this position, he instigated a high-profile campaign against tax evasion. The question now is, whether Mrs. Woerth was aware of the heiress tax evasion practices and the plans of her husband to campaign against it. Mr. Woerth is said to have failed to act on prosecutors' letters of suspicion on Bettencourt's tax evasion. The question is also what role the illegal donation from Mrs. Bettencourt to Sarkozy's election campaign has played. These accusations have come months after earlier allegations of nepotism when Sarkozy's 23-year-old son Jean was tipped to head the public agency running Paris's La Défense, one of Europe's biggest business districts. The outgoing director Mr. Devedjian, a key figure in Sarkozy's UMP party, supported this candidature [25]. Who is trading influence in this case? Who is influencing for whom?

Corruption. Before applying article 12 to these cases, clarity needs to exist whether these cases meet the definition of corruption. Since the Council of Europe has not defined corruption, the definition of Transparency International (hereinafter 'TI') will be used for further analysis. TI defines corruption as: 'The abuse of entrusted power for private gain [1]. In the first case DSB's CFO Gerrit Zalm is entrusted with the ultimate responsibility for achieving DSB's financial goals. The business model and malpractices of the bank have far-stretching consequences and neither Zalm nor the CEO Dirk Scheringa take responsibility for this. Entrusted power to safeguard company interest has completely overruled responsibilities towards customers' interest. The supervisor DNB does not redress these malpractices. Hereby, Zalm's 'being in office', seems to have lead to DNB holding back their strict monitoring and supervisory tasks to DSB. Entrusted power from the CEO, CFO and DNB have been abused and all parties gain from it. The CEO and CFO can stay in their position and the DSB keeps its banking licence.

Sarkozy and Mr. Woerth are public officials who have secretly received a huge amount of money to fund their party's election campaign with the winning of the election as an outcome. Here abuse is not respecting the laws regarding the funding of political parties and election campaign. Their private gain can be found in many respects varying from winning office to the indirect effect of ensuring jobs for respectively, a son and a wife. Also abuse of entrusted power can be found in Mr. Woerth's rejecting the appeal to do investigations into Mrs. Bettencourt's tax evasion.

Trading in influence. Is this a case of trading in influence? What happened when former Minister of Finance Zalm was appointed as CFO? Zalm was a well-respected man who had years of experience in politics. Appointing such a famous and trustworthy face to 
your bank immediately improves the reputation of your bank and increases public trust in your products. In such a situation something else happens. In the back of their minds, supervisory institutions know that one of country's best financial experts is the CFO of this bank. Could it be that DSB intentionally opted for a man in position which made the image of the bank more sound and solid? Do the supervisors lack in supervision and scrutiny now that the 'ambassador' was to be trusted? Did Zalm know that it was not only his skills and knowledge that were bought but also the outlook of less strict supervision on the bank? How is it possible that all parties involved acted the way they did? How can it be, that even after AFM's negative judgment on Zalm's functioning at DSB, he can remain in place as $\mathrm{CEO}$ for the state-owned ABN Amro bank? This was the system which was created and which can be seen as trading in influence.

In the Sarkozy case several actors are involved in trading in influence. Sarkozy is alleged to have picked up an envelop with cash from Mrs. Bettencourt and it is likely that this has influenced Mr. Woerth's decision not to enforce tax regulations on Mrs. Bettencourt in return. This refraining for enforcement is the 'non-acting' which is the advantage for Mrs. Bettencourt. Here both men have abused their entrusted power to influence decision making. After being elected, Sarkozy has allegedly played a role in his son's candidature for the role of director for La Défense, which can also be seen as influencing decision making.

Act. Article 12 reflects a classical approach now that trading in influence is referred to as being an act. The "promising, giving or offering, directly or indirectly, of any undue advantage to an intermediary" is difficult to distinguish. The problem is that in the first case, it is not an act in itself which is corrupt; appointing a former Minister of Finance as a CFO to a bank is not a corrupt act. The indirect effect such an appointment has on supervisory institutions, which are less likely to screen and investigate such a bank, makes this refraining to supervise or redress an "undue advantage" resulting from the misuse of influence. The fact that Zalm remains to be the CEO of a state-owned bank after the supervisory institution's criticism, is difficult to understand and a clear sign of ongoing influences by forces which are difficult to distinguish.

In the second case it is somewhat easier to distinguish one or more acts. Naturally, the alleged financing by Mrs. Bettencourt of UMP's election campaign is illegal and bares the element of "promising, giving or offering, directly or indirectly, of any undue advantage to an intermediary" being minister Woerth who in return granted the "undue advantage" not to investigate tax evasion allegations. Even if it would be undisputed that Mrs. Bettencourt paid cash in return for the Minister of Finance not to enforce tax regulation on her, we would pass by completely on what is really happening here; the environment in which these parties behave the way they do. Here several persons and public officials are involved in a complex system of influencing and being influenced. First, Mr. Woerth, having taken on several positions which created conflicts of interest. Secondly, the appearances against Sarkozy that he won because he received an illegal donation. Thirdly, tax evasion investigations by prosecutors which were not taken on by the responsible Minister Woerth, possibly in return for the donation to his party or because his wife's job depended on his refusal to enforce. Mr. Woerth might also have tried to secure his position as a Minister by these 
means. Fourthly, Sarkozy is alleged of using his influence to arrange the candidature for his son, which would have led to nepotism. The case as a whole shows how actors use and exchange power and wealth to influence decision making. Applying article 12, by picking out single acts is not only difficult but does not do justice to the overall seriousness of unjustified influencing practices which reinforce one another and reflect the systemic character of trading in influence in this case. The seriousness is the fact that all influencing practices are interrelated to each other and create unfair and immoral rules of the decision making game with far reaching consequences.

Corrupt trilateral relationship. According to the COE Convention's Explanatory Report, the trading in influence phenomenon bares the feature of a corrupt trilateral relationship [15, paragraph 64-67]. An intermediary actor "asserts or confirms that he/she is able to exert an improper influence over the decision making of any person referred to in article 2, 4 to 6 and 9 to 11". The persons referred to in these articles are: domestic and foreign public officials, members of domestic and foreign public assemblies and international parliamentary assemblies, officials of international organizations and officials in international courts. National law of the State in which the person in question performs that function and its application in criminal law, determines who falls under these categories [7, art. 1a]. Although it is reasonable to consider situations beyond the classic two party bribery cases and consider the middlemen or intermediary who is the link between those who want to have access and those who have it, this again would only be an effective description for those situations in which an act can be discovered and actors involved can be identified. In the DSB case there is a corrupt literal relationship to distinguish. Dirk Scheringa (DSB), Zalm and DNB create a system in which improper influence over the decision making is the result. Zalm would most likely be the intermediary but since there is no corrupt act to distinguish, it is impossible to describe the roles and behaviours of the actors in the construction of a corrupt trilateral relationship. Trying to apply this element would be artificial.

Distinguishing a clear trilateral relationship in the Sarkozy case would not help to increase our understanding of trading in influence either. One could try to draw lines between two, three or even more actors exchanging wealth and power in exchange for undue advantages or influences on decision making processes, either directly or via an intermediary. This can only be done after using the classical approach of analysing the corrupt acts however it is the complex network of interrelated actors and their features and characteristics which create a trading in influence environment.

Outcome. States have not criminalized trading in influence according to the requirements of article 12 because they feel that it does not offer a clear, solid and efficient description of trading in influence. Most States try to deal with the phenomenon via the criminalization of other offences such as bribery. The fact that from the provision it remains unclear what can be regarded as justified and unjustified influencing strengthens their believe to keep their reservation to article 12. From applying article $12 \mathrm{COE}$ Convention on two actual cases, it has become apparent that the provision does not provide a solution for scrutinising the trading in influence phenomenon. Criminalising 
trading in influence on the basis of this provision, would be a passing by of the systemic character of trading in influence. Extracting an individual case and trying to prosecute actors involved will be challenging at least and won't change the system or help us in our understanding of it. Systemic responses are necessary to deal with systemic problems [17, p. 196]. If we really want to prevent trading in influence we should try to get a better understanding of how this system works. Here trading in influence is systemic, wealth, power and influence are often used in a legal way but it impairs the institutions and creates distrust from citizens. The system has created the way these actors act and try to influence decision making processes. These influence processes pose major questions about relationships between wealth and power in democracies. Although the investigation is still ongoing, cases such as these ones do shine an interesting light on the phenomenon.

\section{Systemic approach to trading in influence}

The provision of article 12 is illustrative for the classical approach of international organizations towards corruption. It is only sufficient in dealing with cases of trading in influence such as the cases of the influence peddling by the Duchess of York and the British MP's Margaret Moran and Cabinet Ministers Geoff Hoon and Patricia Hewitt, who offered political influence for money [27 and 19]. Here a clear act can be distinguished and there is an intermediary who exerts influence over the decision making of a third person. The systemic character of trading in influence means that it is deeply embedded in society and its development. Johnston describes this as a 'collective state of being'. This form of corruption revolves around access to and advantages within institutions rather than deals and connections circumventing them [17, p. 42]. Governments and international organizations need to establish a bigger picture and look at the context in which these forces interact and which elements (actors, structures, and processes) create these forces. Rather than isolating trading in influence we need to understand which components of the liberal democracies and market economies influence one another and form an incentive for trading in influence. Currently States and international organizations still have a classical approach to corruption by focussing on the corrupt act through criminalising it. Other action-approach regulation attempts to prevent trading in influence, can be found in laws on the financing of political parties and election campaigns and in regulations restricting lobbyists' activities and mandate disclosure of their activities. Also soft-law instruments have been introduced, such as the obligations for public officials to be open and transparent on their other activities and private interests, to prevent trading in influence or at least minimise the risks of it taking place. Besides the fact that these measures do not solve the phenomenon, according to Johnston these can even have the detrimental effect of increasing the public perception that 'everything is for sale' and thereby create an even bigger distrust towards to governments, institutions and public officials [17, p. 64-73]. In order to design effective anti-trading in influence policy, states and international organization need to understand the forces behind the phenomenon. By studying the phenomenon and its coming into existence, a better understanding will be created, which can result in a solution to the phenomenon which will find less resistance than the provision of the COE Convention. This way a more comprehensive framework can be 
developed which will be supported by the Council of Europe and its Member States. This study should focus on the way wealth and power are creating an environment in which formal and informal rules are set. The role of influence is not to be banned because this is at the foundation of the political and economic competition of the European democracies and economies [20, p. 124-138]. By understanding these processes a clear picture will arise on the systemic character of trading in influence. Initiatives to decrease trading in influence can only be successful if it is considered in its context. Such a study will have to take place through a multidisciplinary approach. The analysis will also help to understand the role of networks of families, friends, political parties and the individuals' role in these networks. Related phenomena such as nepotism and favouritism will also be better understood and taken into account.

Lessons learned from dealing with other challenges in society via the systemic approach need to be considered [23]. The debate on trading in influence can be compared with the debate on sexual harassment. Both phenomena are widely recognized as immoral and as being offences, nevertheless they both can best be described as syndromes, with on the one hand clear features of wrongful acts but on the other hand with manifestations for which it is not so straight forward to distinguish justified from unjustified behaviour. For example, it seems to be equally difficult to determine whether an unwanted pat on the shoulder from a colleague can be seen as a form of sexual harassment as it is difficult to determine whether a member of parliament who introduces an amendment to a legislation proposal does so because he was influenced by a third party.

The difficulty in criminalising trading in influence is that the corrupt act is not obvious now that influence is bought and not a concrete decision. Whether an official is influenced is often difficult to proof because the causal connection between the actor who acts and the actor who is being influenced is not so clear and remains difficult to investigate and proof. Whether or not Member States agree that a general criminalization of trading in influence and specified legislation is the most effective instrument, Carr stresses the importance of enforcement of anti-corruption legislation by stating "regulation in the absence of enforcement is meaningless at best, it is a political exercise that does not serve the citizens of a State well". Carr hereby emphasises the importance of sophisticated investigative techniques, both overt and covert [5, p. 142].

Analogue to the sexual harassment policies, there should be a focus on individual's and companies' responsibilities and initiatives [18]. In many countries employers are legally responsible for creating a professional climate in which sexual harassment of employees is prevented. If an incident occurs employers have to act, investigate and correct. Similar, not only the actors involved are being held responsible for their trading in influence but also the organizations to which they are an employee can become liable. By analogy, an employer should be made responsible for the trading in influence by a senior employee. Employers are liable for non-senior employees unless they can prove that they exercised reasonable care to prevent and promptly correct any unjustified influencing. This is a 'duty of care' for employers to achieve the result of their employees not being involved in trading in influence. Raising awareness and discussing situations which employees can come across and which are seen as trading in influence are important for achieving this duty of care. 
If we want every professional to have this moral awareness, we need to create this at a young age. The foundation for becoming an honest person is created at a young age, by a child's parents and teachers. They are the ones who teach young people the values such as empathy, compassion, self discipline and altruism which go hand-in-hand with integrity. Nobody can foresee with which situation an individual will be confronted during his life. Therefore it is important that people develop a strong moral compass which they can rely on in different professions and in different situations. Especially when trading in influence is involved, the element which makes the behaviour corrupt is the 'intention' to influence someone or to become influenced. By creating moral awareness via education, people become aware of their behaviour before they become a professional.

The policy to decrease trading in influence has to be coordinated with the entire set of policies which relate to corruption. Through the instrument of mainstreaming unjustified influencing issues are brought right into the core of all policy work, so that they are central to all activities such as legislation, policy development, research, dialogue, resource allocation, implementation and monitoring of programmes and projects.

\section{Concluding remarks}

Trading in influence is a form of corruption which is difficult to capture and understand. Nevertheless GRECO is consistently trying to convince States to criminalize this form of corrupt behaviour and thereby making it a criminal offence. Some Member States refuse to comply with this expectation because they fear a climate where there is no room left for lobbying activities or any form of influencing. Other Member States keep their reservations because they find the COE provision on trading in influence complicated and unclear. General descriptions of possible trading in influence situations provided by GRECO have not brought the required clarification. States prefer to have their bribery provisions at hand in case they need to investigate and enforce law regarding a case in which influence was traded. Other States stress the fact that now that this act is lawful in one State and illegal in another, inequalities in competition are created. By trying to apply the provision on two real cases, its ineffectiveness became clear. The way influence was being traded in both the Dutch DSB case and in Sarkozy's case, did not meet the classical provision of the COE Convention. Article 12 of COE Convention focuses on a clear distinguishable corrupt act which takes place within a corrupt trilateral relationship. To the contrary, the trading in influence cases reflect a particular corruptness because they have become a corrupt system with far more immoral and undue effects then the single corrupt acts which might or might not be distinguishable. In these systems all influencing practices are interrelated to one another and these unfair and immoral ways to influence the decision-making game have far-reaching consequences. In the first case, the systemic character of trading in influence becomes imminent from the legal appointing of a former Minister of Finance as a CFO for a Dutch bank, which leads to the misuse of influence on the central bank which monitors this bank. In the second case, trading of influence acts such as the illegal financing of Sarkozy's election campaign by Mrs. Bettencourt can be distinguished. However, such a distinction does not 
do justice to the seriousness of the whole trading in influence system in which different actors with multiple roles and conflicting interests influence directly and indirectly decision-making processes. Both cases are exemplary for this form of corruption and have implications far greater then the ones immediately apparent. Nevertheless, they provide an example of the trading in influence phenomenon, which is symptomatic in western societies. Developments of the last two decades have changed the ways western societies exchange power and wealth in order to influence. As a result, systems have emerged which are used by all parties to influence decision making, whether it be with lawful or illegal means. Even when single acts are not corrupt they can be part of a system which bares the features of trading in influence now that an overall situation is created where a person misuses his influence over the decision-making process for a third party. A far greater focus should be on understanding how this system works; grasping how we use the system to create trust and exert influence in return for money, wealth or any advantage.

Instead of striving to find the perfect definition for this phenomenon and instead of seeing the criminalization of this phenomenon as the goal, it is crucial to aim for a better understanding of the phenomenon. Fear of creating a zero-tolerance approach towards influencing is keeping States and organizations from designing effective policies which protect justified influencing and tackle unjustified influencing. The Council of Europe and its Member States share a common ground and aim to tackle trading in influence. Nevertheless their disagreement regarding the instruments required, have left them powerless to make a difference. By putting trading in influence on their respective agendas and regarding it with a multidisciplinary approach, a real image of the phenomenon will emerge. Basic object for studying is the system in which influencing takes place. This means studying society and the way we have organized it. According to Johnston political contributions and influence processes in democracies are not inherently corrupt but they pose major questions about relationships between wealth and power [17, p.86]. Complex phenomena have never kept scientists, policy-makers and politicians from trying to deal with them effectively. Other phenomena such as terrorism, climate change or even sexual harassment at workplaces have led to debates, research projects and policy design in which the system or environment which created these phenomena have been studied thoroughly. We can learn from these 'past' challenges when considering how to deal with trading in influence and thereby creating European democracies and economies in which influence processes are not hindered but which take place in an honest and fair way.

\section{References}

1. About Transparency International. http://www.transparency.org/about_us [2011-01-02].

2. Ali Khan, L. A Theory of Universal Democracy: Beyond the End of History. Kluwer Law International, 2003.

3. Articles 47 and 48 of the Dutch Criminal Code (Wetboek van Strafrecht) http://wetten.over heid.nl/zoeken_op/BWBR0001854/EersteBoek/TitelV/Artikel47/geldigheidsdatum_07-01-2011 and http://wetten.overheid.nl/zoeken_op/BWBR0001854/EersteBoek/TitelV/Artikel48/gel digheidsdatum_07-01-2011 [2011-01-07].

4. Barney, D. The Network Society. Polity Press, 2004. 
5. Carr, I. Fighting Corruption Through Regional and International Conventions: A Satisfactory Solution? European Journal of Crime, Criminal Law and Criminal Justice, 2007, 121-153.

6. Castells, M. The Rise of the Network Society. Oxford: Blackwell, 1996.

7. Council of Europe Criminal Law Convention on Corruption, 1999.

8. Duchess of York Stung in Influence-Peddling Video. http://www.nytimes.com/ 2010/ 05/24/world/europe/24britain.html, consulted on [2010-07-31].

9. Evaluation Report on Denmark on Incriminations (ETS 173 and 191, GPC 2) (Theme I). Third Evaluation Round, Strasbourg, 2009.

10. Evaluation Report on France on Incriminations (ETS 173 and 191, GPC 2) (Theme I). Third Evaluation Round, Strasbourg, 2009.

11. Evaluation Report on Germany on Incriminations (ETS 173 and 191, GPC 2) (Theme I). Third Evaluation Round, Strasbourg, 2009.

12. Evaluation Report on Sweden on Incriminations (ETS 173 and 191, GPC 2) (Theme I). Third Evaluation Round, Strasbourg, 2009.

13. Evaluation Report on the Netherlands on Incriminations (ETS 173 and 191, GPC 2) (Theme I). Third Evaluation Round, Strasbourg, 2008.

14. Evaluation Report on the United Kingdom on Incriminations (ETS 173 and 191, GPC 2) (Theme I). Third Evaluation Round, Strasbourg, 2007.

15. Explanatory Report to the Council of Europe's Criminal Law Convention on Corruption (ETS 173).

16. George, S. and Bache, I. Politics in the European Union. Oxford University Press, 2000.

17. Johnston, M. Syndromes of Corruption: Wealth, Power and Democracy. Cambridge University Press, 2005.

18. Kaptein, M. and Wempe, J. The Balanced Company. Oxford University Press, 2002.

19. MPs and Peers run private company selling 'influence over Government policy' as multinationals pay to join parliamentary IT lobby group. http://www.dailymail.co.uk/news/article1261282/MPs-Peers-run-private-company-selling-influence-Government-policymultinationals-pay-join-parliamentary-IT-lobby-group.html [2010-11-07].

20. Nwabuzor, A. Corruption and Development: New initiatives in Economic Openness and Strengthened Rule of Law, Journal of Business Ethics, 2005, Nr.59, 121-138.

21. Overview on the ratifications and reservations of Member States made to the COE Convention. http://conventions.coe.int/Treaty/Commun/ListeDeclarations.asp? $\mathrm{NT}=173 \& \mathrm{CM}=$ $1 \& \mathrm{DF}=\& \mathrm{CL}=\mathrm{ENG} \& \mathrm{VL}=1$ [2010-12-14].

22. Peçi I. and Sikkema E. Corruption and legal certainty; the case of Albania and the Netherlands Implementation of the Criminal Law Convention on Corruption in a transitional and consolidated democracy, Utrecht Law Review, 2010, Vol. 6 No 1, 101-118.

23. Rowe, M. Dealing with Harassment: A Systems Approach, Sexual Harassment: Perspectives, Frontiers, and Response Strategies, Woman \& Work, 1996, Nr. 5, 241-271.

24. Run on DSB bank makes Dutch central bank take control. http://www.nrc.nl/interna tional/article2384565.ece [2010-08-14].

25. Sarkozy's son sparks nepotism row after being tipped for top public job.http://www. guardian.co.uk/world/2009/oct/09/jean-sarkozy-nepotism-row [2011-01-02]. 
26. Saxion/Tiri-Pien Conference paper on Influence Marketing. http://www.corruptie.org [2011-01-07].

27. Stephen Byers claims no rules were broken during lobbying sting. http://www.guard ian.co.uk/politics/2010/mar/21/lobbying-sting-labour-mps-influence [2010-08-07].

28. The United Kingdom's 1906 Prevention of Corruption Act. http://www.cps.gov.uk/le gal/a_to_c/bribery_and_corruption/[2010-08-05].

29. United Nations Convention against Corruption, 2004.

30. Van Hulten, M. State of anti-corruption and integrity in the Netherlands: International \& Comparative. Saxion University of Applied Sciences and Transparency International Nederland, 2010.

31. Van Schendelen, R. Machiavelli in Brussels: The Art of Lobbying the EU. Amsterdam University Press, 2002.

32. Wellink, Zalm Tarnished by Collapse of Netherlands' DSB Bank. http://www.bloomberg. com/apps/news?pid=newsarchive\&sid=arOjxbSxN37Y [2010-09-03].

33. Zowel Zalm als de AFM beschadigd http://www.nrc.nl/economie/DSB/article2495532. ece/Zowel_Zalm_als_de_AFM_beschadigd [2010-08-14].

Willeke Slingerland

\section{Kova su prekyba įtaka}

Anotacija

Tariant, kad prekiavimas įtaka yra netinkamas asmens poveikis kitų asmenų, institucijų ar valdžios įstaigų sprendimams, siekiant asmeninès naudos ir akcentuojant, kad Europos Taryba griežtai pataria valstybėms narems laikyti tokią įtaką nusikalstama, straipsnyje aptariamos skirtingos pozicijos dèl būtinybės tokią veiklą įvardyti kaip korupcinę, pateikiant argumentus už ir prieš, kad tokia veikla laikoma nusikaltimu. Argumentai grindžiami skirtingais praktiniais ir moraliniais motyvais. Aptarta, kaip veikia Europos Tarybos konvencijos dėl korupcijos kriminalizavimo 12-asis straipsnis analizuojant konkrečius Olandijos ir Prancūzijos pavyzdžius. Pateikta, kad šios konvencijos nuostatoms igyvendinti trukdo tai, kad dėmesys skiriamas pačiam korupcijos veiksmui. Prekyba įtaka geriau gali būti suvokiama kaip turto ir galios mainai, o pats veiksmas nèra taip aiškiai išskiriamas. Nurodoma, kad sisteminis požiūris ị prekybą ịtaka yra esminis reikalavimas siekiant sukurti ir igyvendinti efektyvias priemones, kaip kovoti su šiuo reiškiniu.

Willeke Slingerland - Olandijos Saxion taikomujų mokslų universiteto Valdymo ir teisès mokyklos lektorè.

E. paštas: w.slingerland@saxion.nl

Willeke Slingerland, is a Lecturer at the Saxion University of Applied Sciences (School of Governance \& Law), the Netherlands.

E-mail: w.slingerland@saxion.nl

Straipsnis įteiktas redakcijai 2010 m. rugsèjo mèn.; recenzuotas; parengtas spaudai $2011 \mathrm{~m}$. sausio mèn. 